University of Nebraska - Lincoln

DigitalCommons@University of Nebraska - Lincoln

2-1-1997

\title{
The Effects of Charges of Corruption on Voting Behavior in Congressional Elections, 1982-1990
}

John R. Hibbing

University of Nebraska-Lincoln, jhibbing1@unl.edu

Susan Welch

Follow this and additional works at: https://digitalcommons.unl.edu/poliscifacpub

Part of the Political Science Commons

Hibbing, John R. and Welch, Susan, "The Effects of Charges of Corruption on Voting Behavior in Congressional Elections, 1982-1990" (1997). Faculty Publications: Political Science. 14.

https://digitalcommons.unl.edu/poliscifacpub/14

This Article is brought to you for free and open access by the Political Science, Department of at DigitalCommons@University of Nebraska - Lincoln. It has been accepted for inclusion in Faculty Publications: Political Science by an authorized administrator of DigitalCommons@University of Nebraska - Lincoln. 


\title{
The Effects of Charges of Corruption on Voting Behavior in Congressional Elections, 1982-1990
}

\author{
Susan Welch \\ The Pennsylvania State University \\ John R. Hibbing \\ University of Nebraska
}

\begin{abstract}
Fifteen years ago, Peters and Welch investigated the effects of corruption charges on the outcomes of U.S. House elecrions. Their evidence from 1968 to 1978 indicated that charges generally produced a decline in vote share of between $6 \%$ and $11 \%$, depending upon the nature of the charge. Morals violations were the most consequential for candidates and conflict of incerest the least. Continuing changes in American politics and the nature of campaigns have made carruption charges even more common and, indeed, central to many races. In the following research note, we explore whether the changing nature of congressional campaigns has altered the magnicude of the effects of corruption charges on congressional election outcomes.
\end{abstract}

$\mathbf{N}$

early two decades ago, two observers of the American polity wondered, "If political corruption is in the mainstream of American politics, why is it not in the mainstream of American politics research?" (Peters and Welch, 1978, 974). Given the candidate-centered nature of modern congressional elections, the extent to which the status of the candidates in the race shapes the campaign, and the importance of charges of corruption to a candidate's status, the role of corruption charges in elections should indecd be center stage on the rescarch agenda of American electoral scholars. Surprisingly, however, work on the impact of corruption is still rare (but see Rundquist, Strom, and Peters 1977). Peters and Welch (1980) provided the most direct treatment of the topic, but their data end with the 1978 election.

Yet, the two decades following Watergate produced major changes in the American polity, including, if anything, increased press and public attention to corruption and scandal. The check-kiting scandal of 1992 did lead to an amazing amount of research on its effects in the 1992 congressional elections (see Ahuja et al. 1994; Groseclose and Krehbiel 1994; Jacobson and Dimock 1994;

We thank John R. Alford for allowing us to use portions of his data set on congressional elections.

The Journal of Politics, Vol. 59, No. 1, February 1997, Pp. 226-39

(C) 1997 by the University of Texas Press, P.O. Box 7819, Austin, TX 78713-7819 
and Stewart 1994),' but it was, after all, a single election dominated by a unique set of factors. The circumstances do not permit general statements on the typical consequences of corruption charges. It is, therefore, certainly time to reexamine the consequences of corruption charges to see if changes in the polity are reflected in changes in the electoral consequences of corruption.

\section{Past Findings and Current Expectations}

\section{Why' Corruption Allegations Are Potentially Important}

Candidate-centered congressional elections are now the norm. Though the decline of political parties is not as marked as is occasionally maintained, it is still notable. This is especially true of congressional elections where tiny seat shifts, even in years where partisan winds change significantly (such as five in 1988, eight in 1990, and 10 in 1992), are much more common than past shifts of occasionally epic proportions (such as 116 in 1894, 71 in 1938, and 74 in 1994). National forces such as the economy (Erikson 1990) and presidential coattails (Calvert and Ferejohn 1983) seem to have relatively small effects on House seats. Moreover, "average" performance often does not reflect individual party contestants. The standard deviation around mean party shifts from one election to the next nearly doubled from the early 1950s to the early 1990s (see Jacobson 1992, 36; also see Jacobson 1987 and Mann 1978). With the conspicuous exception of 1994, candidates' electoral performances seem increasingly to be the product of their own situations, opponents, and campaigns. And, given the relatively small role of issue voting in elections, the candidate-centered nature of the race means that much of what is left is a rumor of scandal, an allegation of impropriety, or a charge of corruption.

Given the potential importance of these charges to a candidate's fortunes, and the significant amount of theorizing about corruption (see Benson 1978; Heidenheimer 1970; Lippman 1930; Peters and Welch 1978; Rogow and Laswell 1963; Thompson 1993; Wilson 1966), it is surprising that little has been done to determine the empirical consequences of corruption charges in Congress. ${ }^{2}$ One exception is an article by Peters and Welch (1980). These authors begin by asking why charges of corruption so seldom spell the end for a politician and conclude by noting that, while there are negative repercussions, most incumbents during the time period they studied had a safety zone of sufficient size to survive the loss of the 6 to 11 percentage points in electoral margins that charges of corruption bring about.

\footnotetext{
'The check-kiting situation offered a continuous measure of involvement (did the member kire 15 checks or 615?), and thus an unusualiy attractive feature for corruption research.

${ }^{2}$ Theorizing has often focused on the municipal level.
} 
Polential Change Since the 1970s

While much has changed in American politics since the 1970s, when Peters and Welch collected their data, we expect that the electoral impact of corruption has increased only modestly. Over the years, corruption, scandals, and assorted alleged misdeeds have become ever more widely publicized. The continued lack of policy awareness of many voters and the continued decline of political parties as voting cues mean that image-based variables have become more central. Many candidates appear to believe that a good way to differentiate their image from their opponent's is to levy a charge of impropriety or corruption. Thus, campaigns have increasingly been focused on an opponent's moral character, personal finances, utilization of perquisites, family life, daily habits, and related matters.

Still, while these issues seem to be more consistently in the press and on the public mind than before, this does not necessarily mean that the charges are more devastating. Allegations may be farfetched, as candidates recognize the potential for accusations in the current climate. Candidates may try to smear their opponents with misbehavior of relatives or make political hay from minor transgressions such as speeding. And in the most salient contests, voters may weigh the nature of the charges against other things they know about the candidates. ${ }^{3}$ Thus, the second factor may mute the first: charges of corruption have more potential but are sometimes more trivial, so the reaction of voters may not be substantially more negative to such charges.

Another reason we might not expect a great deal of change from the Peters and Welch findings is that their research covered a time when the trends we have emphasized were already underway. In other words, the 1970s were the decade of Watergate, not one of strong parties, a docile media, and ignored charges of corruption. ${ }^{4}$ So there is no reason to expect a radical departure from the definite but measured voter reaction to charges of corruption reported in this earlier research.

Thus, while we expect that charges of corruption will be more frequent in the 1980s and early 1990s compared with the earlier period examined by Peters and Welch, we also expect that the level and nature of voter and candidate reaction to these charges will be only marginally greater than that of the 1970s. Moreover, as in the 1970s, we anticipate electoral consequences to be greater when they deal with "morals" issues, when they lead to some type of formal investigation or even misdemeanor or felony, and when they are leveled at an incumbent rather than a challenger (Peters and Welch 1980). Despite the earlier findings of greater effect of corruption charges on Democratic candidates, we expect little partisan

\footnotetext{
'As when most voters decided the charges made by Gennifer Flowers against then-candidate Bill Clinton were not worthy of much concern.

'A comparison of the modern era co an earles period when parties were truly stronger would be a most intriguing exercise.
} 
difference in electoral impact because we anticipate the short-term effects of corruption allegations to have an effect on Republicans as well as Democrats.

\section{STUdy Design}

Our unit of analysis is the individual candidate in a particular election year. We collected information on every allegation of corruption against any Democratic or Republican general-election candidate in elections from 1982 to 1990. We chose to end our analysis with 1990 rather than extend it through the 1992 and 1994 elections because of the massive redistricting done in some states between 1990 and $1992 .^{5}$

We defined corruption broadly to include not only instances of misuse of powers of office in exchange for personal gain, but also instances of alleged scandals involving morals or crimes not linked to office. Our analytic categories will allow us to disentangle the effects of different types of alleged wrongdoing. We will use the term "corruption charges" to refer to all these misbehaviors.

Our primary data source for incidences of corruption charges was the Congressional Quarterly, particularly the Special Reports on each election, supplemented by information from the Almanac of American Pollics. Since the CQ's data come from its survey of local media and its local contacts, if reports of charges appear in the $C \ell$, they have been circulated widely enough to appear in local media coverage of the race.

For each individual charged with corruption, we created a case containing information about several important predictors of electoral success as well as about corruption charges. These variables included the individual's partisan identity and incumbency status, previous vore margin in the district, and a measure of the national partisan swing. ${ }^{6}$ We also initially included a variable representing terms of office (as did Peters and Welch), but, consistent with recent research (Hibbing 1991), we found that number of terms did not matter. Senior incumbents in the 1980s were no more safe than junior ones.

We then collected information about the nature of the alleged corrupt acts and the outcomes of the charges at the time of the election. The charge was coded into a classification of campaign violations, bribery, other crimes, conflict of interest, abuse of congressional prerogatives, morals charges, and a residual "other" category. In order to estimate the impact of corruption charges, we recorded the vote totals, previous vore totals, party, partisan swing, and incumbency status of

\footnotetext{
${ }^{5}$ And for the same reason, we did not continue the Peters and Welch series by starting with 1980.

${ }^{6}$ For example, if the partisan swing in a year was 5.2 percentage points toward the Democrats (as is was in 1982), this variable took on a value of +2.6 for the Democratic candidates and -2.6 for Republican candidates. The values for each year were coded in similar manner. Welch and Peters used a set of dummy variables representing each election year, so the formulation applied here should provide a more accurate control for overall partisan movements from year to year.
} 
all 435 House contests in the 1982-1990 period. ' Our primary analysis regressed the candidates' vote totals on previous vote share, national partisan swing, and the corruption variable (where being accused equaled 1, and not accused equaled 0 ).

Although we have data on all House elections in the five election years between 1982 and 1990 inclusive, the multivariate analysis excludes certain cases. First, since vote in the previous election (that is, the election at $t-2$ ) is our most important control variable as we attempt to isolate the effects of corruption, we must exclude elections for which we do not have this vote. Specifically, we must exclude 1982 from this portion of the analysis since, because of redistricting, vote in 1980 would be a misleading control. ${ }^{8}$

We also removed all cases in which there was nor the same incumbent in both $t$ and $t-2$ and those in which that incumbent was not challenged in both elections by a person of the opposing major party. This elimination obviously reduces our $N$ but eliminates wild variance from one year to the next that occurs because an incumbent was challenged in one year but not the other. We also excluded openseat races and those races in which both challenger and incumbent were charged with corruption.

\section{Characteristics of THE CORRupTION CHARges}

Before examining the electoral impact of corruption, it is useful to look at background information. Not all corruption charges are the same. They also do not always materialize in the same kind of race for the same type of candidate. Thus, in Table 1 we present the frequencies of certain salient circumstances under which the 116 charges of corruption were made during the decade.

Though the idiosyncratic nature of many of these charges results in a large "other" category, sizable numbers of cases involve campaign violations (13\%), bribery and other crimes (12\%), morals violations (15\%), and, especially, abuse of congressional prerogatives such as the franking privilege, overseas travel, and the like (25\%). Many of the cases in the "other" category involve allegations that the candidate is friendly with, or related to, someone else allegedly involved in misdeeds, including owners of the failed savings and loans.

No definitive over-time pattern is evident, although the 41 corruption charges in 1990 stand out from the others in our data set as well as in the earlier Peters and Welch data. For the large majority of these cases, no criminal action or other

\footnotetext{
'It is important to note that Peters and Welch used only a small number of "non-corruption" cases in deriving their estimates. They randomly selected from cases comparable to the corruption cases. Given the potential for bias in the selection of these cases and the ready availability of data on all House ejections, we have chosen to use all cases in this analysis. The disadvantage of this procedure is that the estimates produced by our multivatiate model will not be strictly comparable to the earlier analysis.

${ }^{8}$ If the district was substantially affected by redistricting between the 1980 and 1982 elections, there are no appropriate controls for 1980 since the 1980 and 1982 districts are essentially different.
} 
TABLE 1

Characteristics of 116 Cases of Allegations of Corruption, 1982-1990

Type of charge

Campaign violations 15

Bribery

3

Other crimes

Abuse of congressional prerogatives $\quad 29$

Morals charges 15

Other 43

Year

$1982-18$

1984

1986222

$1988 \quad 24$

1990

Stacus of charge at time of election

No criminal action

Action taken but charges dropped

Ongoing investigation 4

House eshics commirtee 3

Indictment 2

Conviction 2

Other or undetermined 20

Candidate status

Incumbent 76

Challenger 26

Open seat contestant 14

Party

Republican $\quad 55$

Democrat 61

Region

East 31

South 38

Midwest 21

West 26

Terms Served

$\begin{array}{ll}1 & 12 \\ 2 & 11\end{array}$

$3-4 \quad 14$

$\begin{array}{ll}5-6 & 15\end{array}$

$7-8 \quad 11$

9 or more 13 
official action had followed from the charges by the time of the election (or in most cases, at any time). Incumbents bear the brunt of charges of corruption. Yet only 76 of the 116 candidates charged were incumbents; twelve more incumbents were charged and either voluntarily departed or lost in the primary. Neither Republicans nor Democrats are particularly prone to being charged. Similarly, each region has its fair share of charges, although more are levied against candidates from the South and the East than from other regions. Finally, corruption charges leveled at incumbents are not confined to a certain tenure level. Thirteen percent of those charged had registered 10 terms or more of service, while nearly $16 \%$ were in their first terms. This is close to a proportional representation of the overall membership of the House during the decade (see Ornstein, Mann, and Malbin 1992).

\section{Status of Incumbents Charged with Corruption}

Now we consider what happened to those incumbents who were charged with corruption. A total of 88 occupied this unfortunate category during the five elections covered by our study, an average of 17.6 per election cycle. While this compares unfavorably with the 13.3 charges of incumbent corruption per election between 1968 and 1978, we caution against drawing the conclusion that incumbents have become more corrupt. This may or may not be the case. An alternative hypothesis is that the Congressional Quarterly became more punctilious in reporting charges of corruption. Or, more likely, challengers and the media became more disposed to raise such charges. A third possibility is that, as charges have increased, the definition of improper behavior has become broader; standard practices of the "old" Congress have become suspect today. Some of the allegations of corruption are questionable to say the least, many involving guilt by association or minor illegalities.

The more interesting issue is what happens to those who are charged with corruption, and this information is reported in Table 2. "Voluntary departure," not directly necessitated by electoral defeat, is rarely the chosen route. Resignations are voluntary departures in the middle of a term, while retirements come at the end of a congressional session. Of the 88 incumbents charged with corruption in the 1980 s reapportionment cycle, only $9(10.2 \%)$ decided to leave the House without contesting for a spot in the next Congress. This is a surprisingly small figure and is even a bit smaller than the $12.5 \%$ (10 of 80 ) reported for the earlier (1968-1978) time period. Moreover, the 10\% of those charged with corruption departing voluntarily is just barely higher than the percent departing voluntarily who were not charged with corruption: $7.7 \%$ of all uncharged members retired. Thus, a corruption charge only marginally increases the odds a member will depart voluntarily (of course, it is possible that the fear of a corruption charge led others to strategically retire before the accusation was made). 
TABLE 2

Electoral Outcomes of House. Members ACCUSED OF CORRUPTION, 1982-1990

\begin{tabular}{|c|c|c|c|c|c|c|}
\hline Electoral outcome & 1982 & 1984 & 1986 & 1988 & 1990 & Total \\
\hline Resigned during term & 3 & 0 & 0 & 0 & 3 & 6 \\
\hline Chose not to run again & 0 & 0 & 2 & 1 & 0 & 3 \\
\hline Defeated in primary & 1 & 0 & 0 & 1 & 1 & 3 \\
\hline Defeated in general & 1 & 3 & 1 & 6 & 8 & 19 \\
\hline Won reelection & $\underline{9}$ & 4 & $\underline{10}$ & 14 & 20 & $\underline{57}$ \\
\hline $\begin{array}{l}\text { Total incumbents charged } \\
\text { with corruption }\end{array}$ & 14 & 7 & 13 & 22 & 32 & 88 \\
\hline $\begin{array}{l}\text { Percent of charged incumbents } \\
\text { running in general election } \\
\text { who won }\end{array}$ & 82 & 57 & 91 & 67 & 69 & 72 \\
\hline $\begin{array}{l}\text { Percent of charged incumbents } \\
\text { who won reelection }\end{array}$ & 64 & 57 & 77 & 64 & 62 & 65 \\
\hline
\end{tabular}

Primary defeats are even rarer than voluntary departures. Only three of the 79 nonvoluntarily departing incumbents charged with corruption were defeated in primary contests (3.8\%). This figure is slightly less than in the 1970 s when about $7 \%$ of corruption-tainted incumbents lost in the primary. More importantly, it is only slightly higher than the primary defeat rate for incumbents not charged with corruption, despite the fact that an incumbent not charged with corruption almost never loses in the primary (it happened just .7\% of the time in the 1980s).

Corruption charges matter more in general elections. From 1982 to 1990 inclusive, 19 of the 76 corruprion-charged incumbents running in the general election were defeated $(25 \%)$. This is an astonishingly high defeat rate when compared to the $2.8 \%$ of noncharged incumbents who lost during this same time period. An incumbent charged with corruption is nine times more likely to lose in the general election than one not so tainted. And this $25 \%$ defeat rate is not a fluke; it is identical to that of the 1970s. Three of four incumbents faced with corruption charges still win, but this is a substantially diminished reelection rate from other incumbents.

All in all, $65 \%$ of corruption-charged incumbents appear in the next Congress, while $72 \%$ of those attempting to secure reelection (primary and general combined) are successful. These figures are very similar to those for the 1968-1978 period, when $61 \%$ of corruption-charged incumbents appearcd in the next Congress while $70 \%$ of those attempting to secure reelection were successful. And these rates are substantially lower than we find for House members in the 1980s not charged with scandal. Fully $85 \%$ of "clean" members returned to the next 
Congress. If we limit the analysis to only those who tried to return to the next Congress, the figure is $92 \%$.

Being burdened with a scandal charge diminishes the odds that an incumbent will be in the next Congress, and most of the danger lurks in general elections. Incumbents generally dislike leaving voluntarily when a cloud hangs over them (though this was not the case in 1992 with the check-kiting scandal). They are not likely to be removed by their fellow partisans in primary elections, but one out of four corruption-charged incumbents loses in the general elections.

\section{The Impact of Corruption Charges on Voting Behavior}

Our goal is to determine whether, with controls for an incumbent's previous vote and the national swing evident in each election year, charges of corruption have an independent effect on the incumbent's vore totals. We include separate terms for charges of corruption leveled against the incumbent and for charges of corruption leveled against the challenger. The key expectation is obviously that there will be a negative relationship between charges of corruption against the incumbent and that incumbent's share of the vote. Further, if these effects in the 1980s are consistent with those of the 1970s, we would expect the coefficient to be between -6 and -10 (see Peters and Welch 1980).

Table 3, column 1, presents the baseline results. They are generally consistent with our expectations. Previous vote is strongly and positively related to "current" vote with a beta (not reported) three times as large as any of the other coefficients in the equation. This is as it should be, since back-to-back congressional elections, particularly those with the same incumbent and consistent twoparty competition, are serially correlated. The national swing evident in each election, weak as it was in many of the 1980s elections, is also significantly and positively related to the electoral performance of individual incumbents. All politics is not local politics.

And, as expected, charges of corruption against an incumbent produce a negative effect on that incumbent's share of the vote. For the races included in our analysis, a reasonable estimate of the mean hit sustained by incumbents charged with corruption is $9.27 \%$, an effect that is, if anything, marginally higher than that calculated by Peters and Welch for the 1970s. On the other hand, the effect of corruption charges levied against challengers is the biggcst surprisc. Our expectation was that challengers charged with corruption would increase incumbents' votes. If charges of corruption hurt incumbents, why would they not hurt challengers? While the small number of challengers who are charged gives us less confidence in our estimates for the effects of these charges, we see that incumbents' vote totals actually decrease when their challengers are charged with corruption. If anything, the effect is larger than that for charges of corruption against the incumbent. The explanation for this surprising negative relationship will be addressed shortly. 


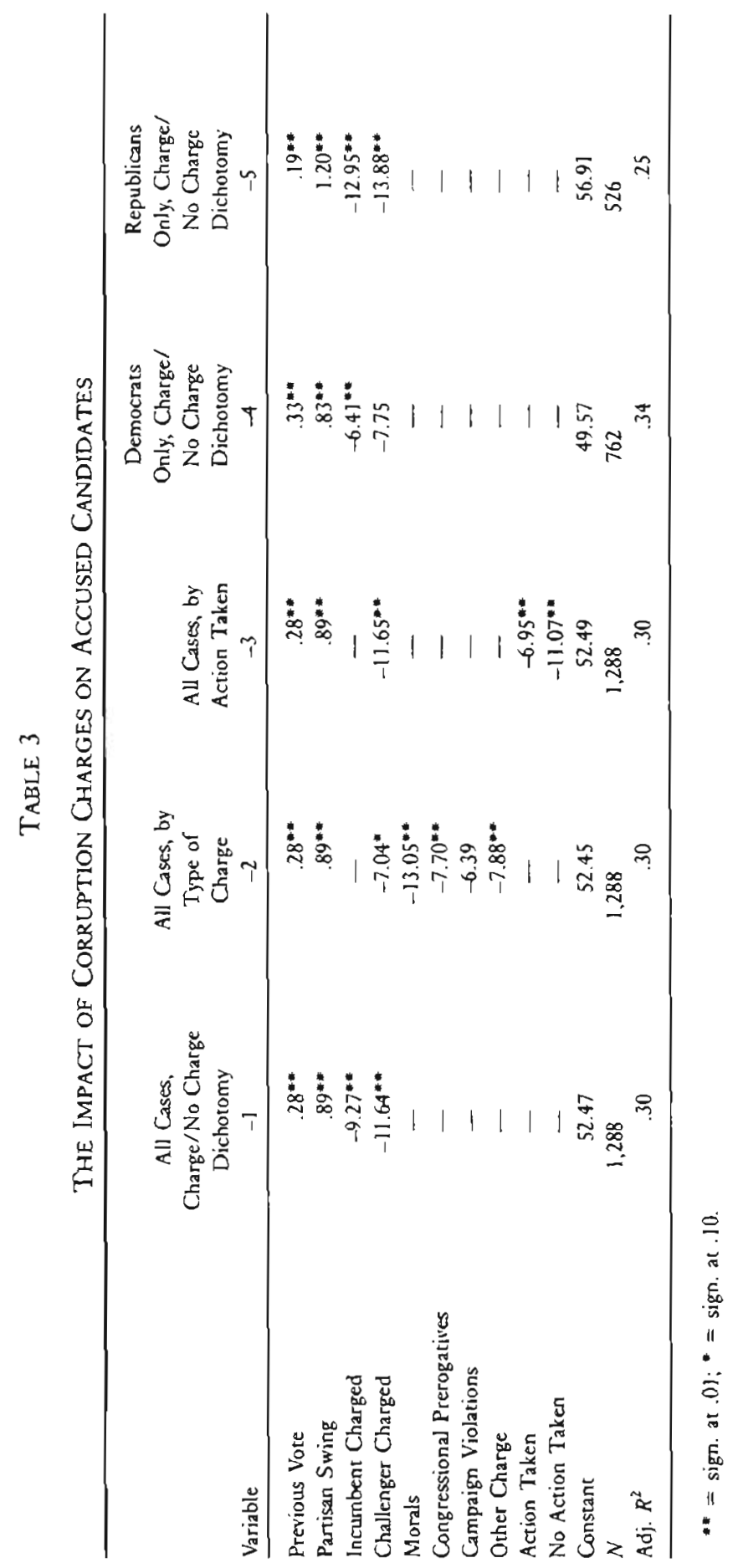


But different types of charges may produce varying electoral consequences. The results in column 2 break charges into those involving "morals," those involving congressional prerogatives, those involving campaign violations, and "other" charges. This parallels the classification employed by Peters and Welch, except that they had a separate category for bribery charges, and we have so few in our data that we included them with the "other" category. While all types of charges hurt incumbents, morals charges, consistent with findings from the 1970s, are by far the most damaging. Other things being equal, when an incumbent is charged with moral corruption a decrease of 13 points is predicted. Other types of charges produce a drop of 6 to 8 points in vote totals.

Perhaps the most important characteristic associated with charges of corruption is whether the charge is accompanied by formal action of some sort, such as an indictment or conviction. Though it would make sense for charges accompanied by some action to be more damaging, in fact only a few charges have formal action associated with them by the time the general election is held (see table 1). There is absolutely no indication that incumbents are hurt by formal actions on the charges. In fact, as column 3 suggests, if anything, the charges that are not accompanied by formal action are more damaging. This cannot be comforting to those who would like to see more care taken before charges are made public.

When incumbents are divided by party, as they are in columns 4 and 5 of Table 3, we find that Republicans are hurt more by charges of corruption than are Democrats. This is not consistent with the findings of Peters and Welch. It is consistent with the general pattern of results indicating that previous vote is less predictive for Republican candidates, leaving more clout to be exercised by national partisan swing, scandal, and presumably other, more idiosyncratic variables. Republicans would appear to have more difficulty capitalizing on a strong showing at $t-2$ but also more ease in overcoming a weak electoral performance at $t-2{ }^{9}$

Finally, we return to the counter-intuitive finding that incumbent vote totals are hurt when their challengers are charged with corruption. Though only a small number of challengers were charged, and though the coefficient for challengers is not statistically significant in all formulations, this coefficient is consistently negative and often quite large; therefore it deserves some comment.

\footnotetext{
${ }^{9}$ A more precise determination of the extent to which charges of corruption affect Republicans differently than Democrats is possible when Democrat*corruption and Republican*corruption are computed and entered into the equation. By constructing a confidence interval around one of the estimates, we can determine the probability that the (wo coefficients are actually different. When this procedure is employed we find that the chances are less than .01 that the coefficients are the same $(-13.5+(2.576 \cdot 2.22)=-.7 .78$ and $-13.5-(2.576 \cdot 2.22)=-19.25)$. Since the value of the coefficient for Democrats is not in the above $99 \%$ confidence interval for Republicans, we can be confident that, in the 1980 s at least, charges of corruption were more telling for Republican incumbents than for Democrats.
} 
The likely explanation for this seemingly unusual finding is that only the more serious challengers are likely to be charged with corruption. Most incumbents prefer to ignore challengers, thereby producing low-salience campaigns. Only if a challenger is a threat is it likely that corruption accusations would be made. This finding is parallel to Gary Jacobson's discovery that high levels of campaign spending actually hurt incumbents even as they help challengers (1980). Charges of corruption as well as incumbent spending are often reactive. Neither the media nor incumbents are likely to charge an inexperienced, underfunded, nonviable challenger with corruption (no one cares enough and the inexperienced candidates are also less likely to have been in a position to engage in corruption anyway).

The data bear this out. The percent of experienced House challengers in 1982, $1984,1986,1988$, and 1990, respectively, is 27,16,14,12, and 10 (Jacobson 1990, 59 ), or on average about $16 \%$ per election. However, in races in which the challenger is charged with corruption, the percentages of experienced challengers are $50,0$ (small $N), 57,50$, and 30 , or an average of about $37 \%$. Obviously, the chances are much greater that experienced-and thus more viable-challengers will be charged with corruption than will inexperienced ones. The nature of modern congressional campaigns, with strong challengers dictating responses by the incumbent and perhaps the press, raises the likelihood that the coefficient for charges of challenger corruption is spurious in a fashion that the coefficient for charges of corruption against the incumbent cannot be.

\section{Conclusion}

The common wisdom that corrupt politicians continue to go unpunished is not altogether on target. Our findings from the 1980 s reinforce those from the 1970s showing that charges of corruption do have an impact on voters. Setting aside 1992, such charges rarely cause incumbent U.S. Representatives to resign, retire, or lose in primary races, but they do often cause them to lose votes and occasionally elections in November. Twenty-five percent of incumbents charged with corruption lose their general election bids-far higher than the trivial defeat rates of those incumbents not charged with corruption. On average, in fact, incumbents receive nearly 10 percentage points less of the two-party vote than they could have expected if they had not been charged with corruption.

The type of charge makes a substantial difference on the expected electoral retribution. Morals violations are the most likely to be punished at the polls. Surprisingly, formal action on the charge did not lead to greater incumbent vote loss, although it is rare for formal charges to have been brought by the time of the election.

The findings summarized to this point are, for the most part, similar to those of the 1970s. But other findings are new. Other things being equal, Republicans may be more vulnerable to charges of corruption than Democrats (unlike the 
situation in the 1970s). More tellingly, the electoral consequences of an incumbent being charged with corruption are quite different from the consequences of a challenger being similarly charged. Ceteris paribus, an incumbent loses 9 to 10 percentage points as a result of a charge of corruption while a challenger actually gains 11 to 12 percentage points, largely because, we argue, experienced challengers are much more likely to be charged with corruption.

But one might still wonder why $75 \%$ of those charged with corruption win anyway. One reason is that knowledgeable individuals may weigh the seriousness of a corruption charge against their closeness to the candidates in partisan or policy preferences (Peters and Welch 1978; Rundquist et al. 1977) or the ability of the candidate to provide economic benefits for the district. Some vorers lack information about either charges of corruption or issues and are steered by their lingering partisan preferences or a casual bit of information picked up from the media. Still others ignore charges of corruption because they believe that all politicians are corrupt so a voter should not bother to single out any for special adverse treatment. And of course, in some cases voters may rightly choose not to believe many of the charges flying around. Thus, despite all of these reasons to discount charges of corruption in an electoral decision, it is striking that such charges lead to the defeat of $25 \%$ of those charged. Corruption allegations, therefore, appear to be responsible for an important share of turnover occurring in Congress.

Manuscript submitted 10 August 1995

Final manuscript received 12 April 1996

\section{REFERENCES}

Ahuja, Sunil, Sraci Beavers, Cynchia Berreau, Anthony Dodson, John R. Hibbing, Parrick Hourigan, Steven Showalter, and Jeff Walz. 1994. "Modern Congressional Election Theory Meess the 1992 House Elecrions." Political Research Quarierly (November): 909-22.

Benson, George. 1978. Politisal Corruption in America. Lexington, MA: Lexington Books.

Calvert, Randall, L., and John A. Ferejohn. 1983. "Coatcail Voting in Recent Presidential Elections." American Political Science Review 77:407-19.

Erikson, Robert S. 1990. "Economic Conditions and the Congressional Vote: A Review of the Macrolevel Evidence." American Journal of Political Science 34:373-99.

Groseclose, Timorhy, and Keith Krehbiel. 1994. "Golden Parachutes, Rubber Checks, and Strategic Retirements from the 102nd House." American Jourral of Polisical Science 38:75-99.

Heidenheimer, Arnold J. 1970. Polieical Corruption: Readings in Comparative Analysis. New York: Holt, Rinehart, and Winston.

Hibbing, John R. 1991. Congressional Careers: Contours of Life in the U.S. House of Representatives. Chapel Hill, NC: University of North Carolina Press.

Jacobson, Gary C. 1980. Money in Congressional Elections. New Haven, CT: Yale University Press.

Jacobson, Gary C. 1987. "I "The Marginals Never Vanished: Incumbency and Competition in Elections to the U.S. House of Representatives, 19\$2-1982." American Journal of Political Science 31:126-41. 
Jacobson, Gary C. 1990. The Electoral Origims of Divided Government. Boulder, CO: Westview Press. Jacobson, Gary C. 1992. The Politics of Congressional Elections. 3d ed. New York: Harper Collins. Jacobson, Gary C, and Michael A. Dimock. 1994. "Checking Out: The Effects of Bank Overdrafts on the 1992 House Elections." American Fournal of Political Science 38:601-24.

Lippman, Walter. 1930. "A Theory About Political Corruption." Vanity Fair 35:61, 90.

Mann, Thomas E. 1978. Unsafe at any Margin: Interpreting Congressional Elections. Washington, DC: American Enterprise Institute.

Ornstein, Norman J., Thomas E. Mann, and Michael Malbin. 1992. Vital Statistics on Congress, 199192. Washington, DC: American Enterprise Institute.

Peters, John G., and Susan Welch. 1978. "Political Corruption in America: A Search for Definitions and a Theory." American Political Science Review 72:974-84.

Peters, John G., and Susan Welch. 1980. "The Effects of Charges of Corruption on Voting Behavior in Congressional Elections." American Political Science Reviem 74:697-708.

Rogow, Arnold, and Harold D. Lasswell. 1963. Pomer, Corruption, and Rectutude. Englewood Cliffs, NJ: Prentice-Hall.

Rundquist, Barry S., Gerald S. Strom, and John G. Peters. 1977. "Corrupt Politicians and their Electoral Support: Some Experimental Observations." American Political Science Review 71:95463.

Stewart, Charles. 1994. "Let's Go Fly a Kite: Correlates of Involvement in the House Bank Scandal." Legislative Studies Quarterly 19:521-36.

Thompson, Dennis. 1993. "Mediated Corruption: The Case of the Keating Five." American Political Science Reviem 87:369-81.

Wilson, James Q. 1966. "Corruption: The Shame of the States." The Public Interest 2:28-38.

Susan Welch is professor of political science and dean of the College of Liberal Arts, Pennsylvania State University, University Park, PA 16802.

John R. Hibbing is professor of political science, University of Nebraska, Lincoln, NE 68588-0328. 